\title{
COMPARATIVE STUDY OF MORPHOLOGY OF VARIOUS FLY ASHES AND POND ASHES FROM DIFFERENT THERMAL POWER STATIONS IN MONGOLIA
}

\author{
U.Bayarzul $^{1 *}$,J.Temuujin ${ }^{1}$, A.Minjigmaa ${ }^{I}$, A.Bekhbaatar $^{1}$, B.Battsetseg $^{1}$ \\ J.Mapiravana ${ }^{2}$, M.Dlamini ${ }^{2}$ \\ 1. Institute of Chemistry and Chemical Technology, Mongolian Academy of Sciences, Ulaanbaatar, Mongolia \\ *E-mail: bayarzuluyat@yahoo.com \\ 2. CSIR Building and Construction Materials and Methods Research Group, Building Science and Technology, \\ Built Environment, Pretoria, South Africa
}

\begin{abstract}
In Mongolia coal fired thermal power stations produce over $90 \%$ of the country's electricity. Three thermal power stations located in Ulaanbaatar city produce more than $80 \%$ of all electricity produced in Mongolia. The annual output of fly ash and bottom ash from these thermal power stations is about 600,000 tons. The thermal power plants in Ulaanbaatar city use coal from Baganuur and Shivee-Ovoo deposits.

This research was conducted to compare morphologies of various fly ashes and pond ashes from TPS in Mongolia. Fly ashes from TPS4 and pond ashes from TPS3 and TPS4 of Ulaanbaatar city were characterized by $x$-ray fluorescence (XRF), transmission electron microscopy (TEM), laser particle size distribution analyzer, specific surface area measurement (BET), and scanning electron microscopy (SEM). The chemical compositions of the fly ashes and pond ashes indicate that they are class $C$ ashes. Specific surface areas of the fly ashes and pond ashes varied from 1.04 to $25.2 \mathrm{~m}^{2} / \mathrm{g}$. Radiation measurements that were performed by $\gamma$-spectroscopy indicate that the radium equivalent changed from 292 to $761 \mathrm{~Bq} / \mathrm{kg}$ in the various ashes.
\end{abstract}

KEYWORDS: pond ash, fly ash, microstructure characterization, specific surface area

\section{INTRODUCTION}

Mongolia is rich in coal with up to 160 million tons of reserves. Coal is also the cheapest raw material for producing electricity and more than $90 \%$ of electricity in Mongolia is produced by coal fired thermal power stations. At present, there are five operating power plants in the centralized energy systems which generate both heat and electricity. These plants burn 5-6 million tons of coal resulting in more than 600,000 tons of coal combustion by-products per year. Within these plants, the $4^{\text {th }}$ thermal power plant generates around 300,000 tons of fly ash and bottom ash. The $3^{\text {rd }}$ thermal power plant produces around 100,000 tons of bottom ash.

The chemical, mineralogical composition and volume of the coal combustion by-products are determined by the content and composition of the inorganic constituents of the original coal, and by the design and operation of the power plant [1-4].Generally, thermal power station coal combustion by-products can be 
divided into different categories, namely:

-Fly ash- pulverized ash extracted from flue gases by any suitable process such as by cyclone separator or electro-static precipitation. Fly ash typically has fine particle sizes.

- Bottom ash-pulverized fuel ash collected from the bottom of boilers by any suitable process.Botton ash has coarser particle sizes.

- Pond ash- fly ash or bottom ash or both mixed in any proportion and conveyed in the form of water slurry and deposited in a pond or a lagoon. Pond ash consists of weathered particles of all sizes.

Fly ash is the best raw material for preparation of geopolymers due to its minimal water content and finer particle sizes. Pond ash is considered the least suitable material because of the high water content and high porosity caused by dissolution of soluble components of fly ash in the water. BET specific surface area of fly ash is about $2 \mathrm{~m}^{2} / \mathrm{g}$, but up to $30 \mathrm{~m}^{2} / \mathrm{g}$ for pond ash [5].

\section{EXPERIMENTAL}

Pond ashes from the TPS3 and TPS4 of Ulaanbaatar city and two different fly ashes from the $4^{\text {th }}$ TPS of Ulaanbaatar city were used for experiments. These fly ashes are residues of the Baganuur and Shivee-ovoo coals.

The chemical compositions of the ashes were determined by $x$-ray fluorescence (XRF); particle sizes were determined using a laser
The majority of coal firing residue from Mongolian TPS cannot be considered as fly ash.

At this time, only the $4^{\text {th }}$ TPS has an electrostatic separator to collect fly ash. Other TPSs are producing bottom ash or boiler slag. The two largest thermal power stations in Ulaanbaatar city are using a huge volume of ash pond to hold the wet coal combustion byproducts. However, due to a land shortage in Ulaanbaatar city, there is a problem to build a new ash pond and the use of pond ash is one of the priorities of coal combustion by products utilization [6]. In order to understand the nature of pond ash and its differences from fly ash, it is necessary to study the microstructure of ash particles. The aim of the present study is to elucidate the morphological and microstructural differences of the various fly ashes and pond ashes using various techniques including high resolution transmission electron microscopy (HR-TEM).

\section{RESULTS AND DISCUSSION}

diffraction particle size analyzer; specific surface areas were measured by a BET analyzer; and particle morphologies were studied using scanning electron microscopy (SEM) and high resolution transmission electron microscopy (HR-TEM). Radiation measurements were performed by $\gamma$-spectroscopy according to Mongolian standard MNS 5072:2001 [7].

Table 1

Chemical compositions of fy ashes and pond ashes

\begin{tabular}{|c|c|c|c|c|c|c|c|c|c|c|c|c|c|}
\hline Samples & $\mathrm{SiO}_{2}$ & $\mathrm{Al}_{2} \mathrm{O}_{3}$ & $\mathrm{Fe}_{2} \mathrm{O}_{3}$ & $\mathrm{CaO}$ & $\mathrm{MgO}$ & $\mathrm{MnO}$ & $\mathrm{K}_{2} \mathrm{O}$ & $\mathrm{TiO}_{2}$ & $\mathrm{Na}_{2} \mathrm{O}$ & $\mathrm{P}_{2} \mathrm{O}_{5}$ & $\mathrm{Cr}_{2} \mathrm{O}_{3}$ & $\begin{array}{l}\text { LOI } \\
(\%)\end{array}$ & Total \\
\hline $\begin{array}{c}\text { Baganuur fly } \\
\text { ash, TPS4 }\end{array}$ & 56.43 & 12.76 & 9.84 & 15.41 & 1.82 & 0.263 & 1.24 & 0.55 & 0.32 & 0.093 & 0.007 & 1.08 & 99.8 \\
\hline $\begin{array}{l}\text { Shivee-Ovoo } \\
\text { fly ash, TPS4 }\end{array}$ & 34.19 & 11.71 & 9.94 & 30.4 & 7.11 & 1.185 & 0.705 & 0.46 & 0.49 & 0.04 & 0.01 & 0.32 & 96.5 \\
\hline $\begin{array}{l}\text { Pond ash, } \\
\text { TPS3 }\end{array}$ & 48.48 & 12.87 & 8.05 & 14.96 & 2.13 & 0.19 & 1.15 & 0.58 & 0.29 & 0.086 & 0.008 & 10.84 & 99.63 \\
\hline $\begin{array}{l}\text { Pond ash, } \\
\text { TPS4 }\end{array}$ & 40.77 & 11.04 & 8.42 & 22.99 & 4.12 & 0.552 & 1.16 & 0.5 & 0.61 & 0.056 & 0.006 & 9.49 & 99.71 \\
\hline
\end{tabular}


Fly ash from lignite and sub-bituminous coals is generally characterized by higher $\mathrm{CaO}$, $\mathrm{MgO}, \mathrm{SO}_{3}$ and lower $\mathrm{SiO}_{2}, \mathrm{Al}_{2} \mathrm{O}_{3}$ relative to the high rank bituminous and anthracite coals. Fly ash from bituminous and lignite coals contains $<10 \% \mathrm{CaO}$ and mainly consist of aluminosilicate glass [8]. Coal from Baganuur and Shivee-Ovoo deposits are lignite type.

The American Society for Testing Materials (ASTM, 2012) groups coal fly ash into three classes: $\mathrm{C}, \mathrm{F}$ and N. Class $\mathrm{F}$ ash shows a combined $\mathrm{SiO}_{2}, \mathrm{Al}_{2} \mathrm{O}_{3}$, and $\mathrm{Fe}_{2} \mathrm{O}_{3}$ content of $>70 \%$ compared to $>50 \%$ for Class $\mathrm{C}$. It is for this reason that sometimes the view held is that class $\mathrm{C}$ ash is derived from lignite and subbituminous coals and that class $\mathrm{F}$ ash is derived from bituminous and anthracite coals [9]. According to the international classification (ASTM) Shivee-Ovoo fly ashes from TPS4 and pond ashes from TPS 3 and TPS4 are Class $\mathrm{C}$ ashes. Loss on ignition of both pond ashes does not vary significantly. The relatively high loss on ignition of pond ashes is characteristic of hydration and hydroxylation of the particle surfaces. It is possible that the pond ashes had hydroxylated surfaces due to water absorption.

Table 2

BET specific surface areas and specific pore volumes of fly ashes and pond ashes

\begin{tabular}{|l|l|c|c|c|}
\hline № & \multicolumn{1}{|c|}{ Sample } & $\begin{array}{c}\text { BET Specific } \\
\text { surface area/ } \\
\mathrm{m}^{2} / \mathrm{g}\end{array}$ & $\begin{array}{c}\text { Pore volume/ } \\
\mathrm{ml} / \mathrm{g}\left(\mathrm{x} 10^{-4}\right)\end{array}$ & $\begin{array}{c}\text { Particle size distribution, } \\
\text { Median diameter, } \mathrm{d}_{50} \text { by laser } \\
\text { analyzer/ } \mu \mathrm{m}\end{array}$ \\
\hline 1 & TPS4, Baganuur fly ash & 2.75 & 2.12 & 27.91 \\
\hline 2 & TPS4, Shivee-Ovoo fly ash & 1.04 & 1.49 & 23.74 \\
\hline 3 & TPS3, pond ash & 25.02 & 10.03 & 24.14 \\
\hline 4 & TPS4, pond ash & 10.13 & 10.05 & 69.14 \\
\hline
\end{tabular}

Specific surface areas of the pond ashes are 10 to 25 times higher and pore volumes are 5 to 10 times greater than those of fly ashes obtained directly from the power plant. These differences suggest that ashes submerged in ponds have undergone a significant chemical and/or physical change by leaching out soluble phases. Loss on ignition of Baganuur fly ash was $1.08 \%$, Shivee-Ovoo $0.38 \%$. The loss on ignition values of the pond ashes of TPS3 and TPS4 were $10.84 \%$ and 9.49 wt.\%, respectively. Keeping ash in an ash pond increases its moisture content possibly causing some hydration or hydroxylation. It also possibly caused increase of the specific surface areas of pond ashes. Median $\mathrm{d}_{50}$ particle sizes derived from the particle size distribution curves indicated that pond ash from the $3^{\text {rd }}$ TPS has almost same median size as the fly ashes. Although pond ash from the $3^{\text {rd }}$ TPS has almost same median size as the fly ashes, the specific surface area is more than 10 fold larger. It suggests that this pond ash may exist in a more hydroxylated state or has been leached out to yield a high specific surface morphology.

Table 3

Isotope activity of fly ashes and pond ashes

\begin{tabular}{|c|c|c|c|c|c|}
\hline \multirow{2}{*}{ № } & \multirow{2}{*}{ Sample } & \multicolumn{3}{|c|}{ Isotope activity concentration, $\mathrm{Bq} / \mathrm{kg}$} & \multirow{2}{*}{$\begin{array}{c}\text { Radium equiva- } \\
\text { lent, } \mathrm{Bq} / \mathrm{kg}\end{array}$} \\
\hline & & $\mathrm{A}_{\mathrm{Ra}^{-} 226}$ & $\mathrm{~A}_{\mathrm{Th}}{ }^{-}{ }_{232}$ & $\mathrm{~A}_{\mathrm{K}^{-}{ }_{40}}$ & \\
\hline 1 & Baganuur fly ash, TPS4 & 242.4 & 31.1 & 381.4 & 314.4 \\
\hline 2 & Shivee-Ovoo fly ash, TPS4 & 262.8 & 48.7 & 215.6 & 342.7 \\
\hline 3 & Pond ash, TPS3 & 683.7 & 40.9 & 299.7 & 761.0 \\
\hline 4 & Pond ash, TPS4 & 195.7 & 53.8 & 334.1 & 292.2 \\
\hline
\end{tabular}


The Mongolian radiation standard for houses and all other public buildings must be less than $370 \mathrm{~Bq} / \mathrm{kg}$ [7]. The radium equivalent of almost all samples was below $370 \mathrm{~Bq} / \mathrm{kg}$ but radium equivalent of the pond ash from TPS3 sample was $761 \mathrm{~Bq} / \mathrm{kg}$. It is important to remember that this requirement is for building materials. Coal combustion by-products are by themselves not building materials. They are raw materials for building materials preparation and are typically diluted on addition of other components [8].

Figure 1

SEM micrographs of fly ashes and pond ashes.

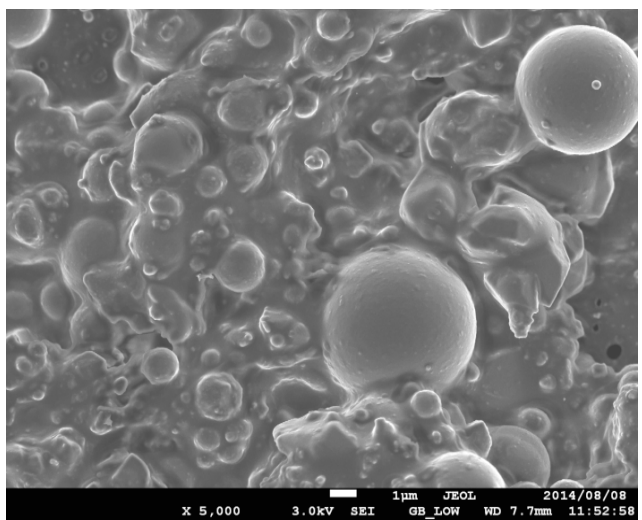

TPS4, Baganuur fly ash

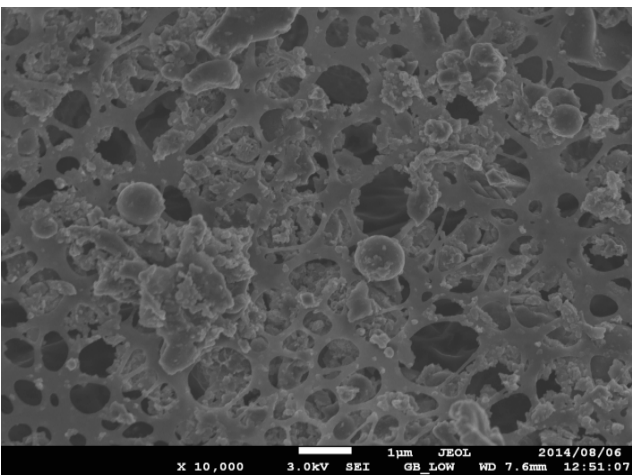

TPS3, pond ash

SEM observation revealed that the fly ashes are predominantly spherical in shape and consist of solid spheres, hollow spheres and some irregular unburned carbon. The micrographs above show that fly ash contains

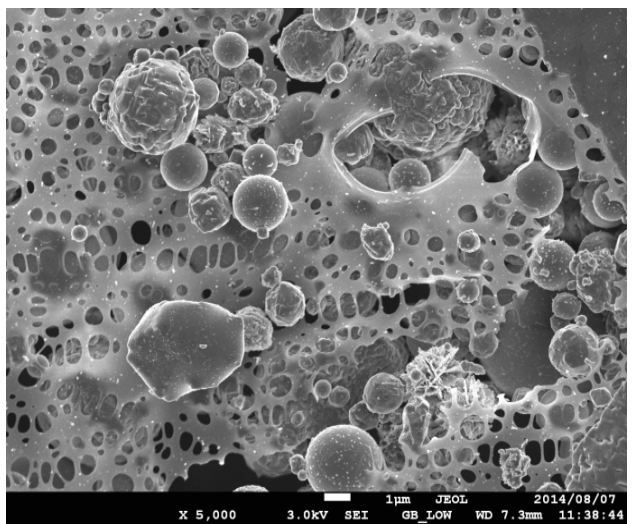

TPS4, Shivee-Ovoo fly ash

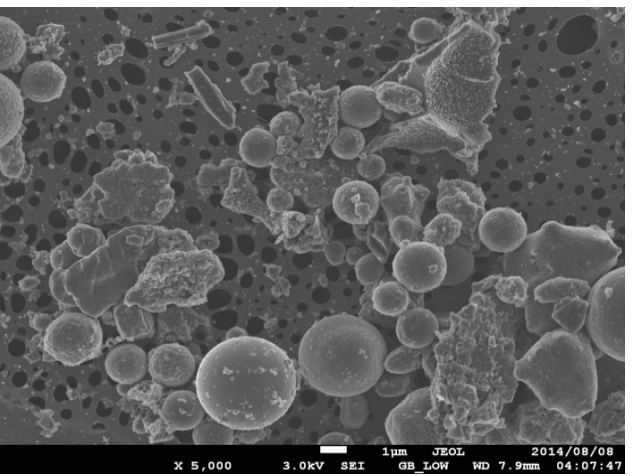

TPS4, pond ash

more spherical particles than pond ash. Pond ash samples have a significantly larger specific surface area and pore volume than the fly ashes obtained directly from the power station. 
HR-TEM micrographs of fly ashes and pond ashes

Figure 2

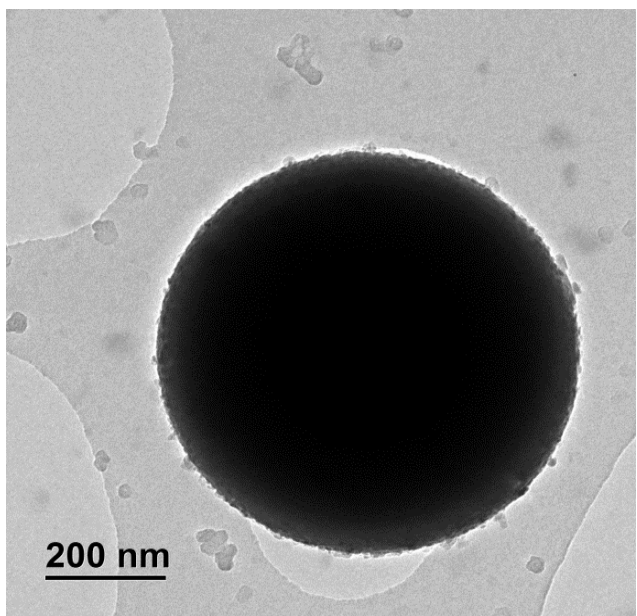

TPS4, Baganuur fly ash

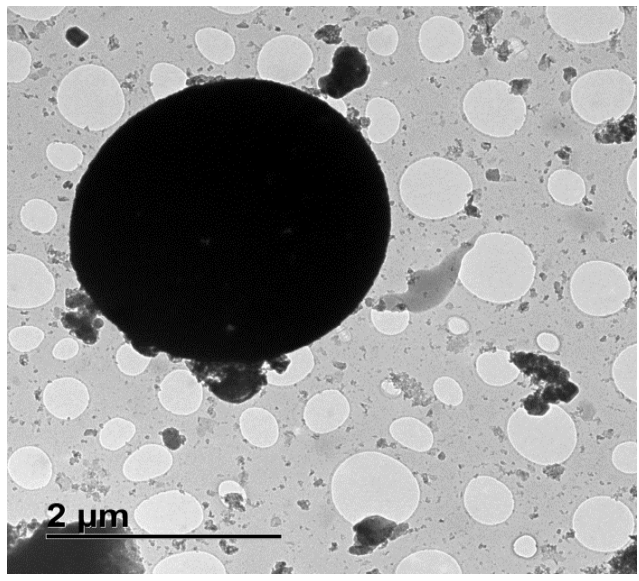

TPS3, pond ash

A difference in structure between the fly ashes and pond ashes can be seen on the TEM micrographs. The surfaces of the fly ash particles were almost smooth without alteration while pond ash particles had partially dissolved

\section{CONCLUSIONS}

Pond ashes had larger specific surface areas and pore volume than fly ashes. Surface dissolution and partial hydroxylation of the pond ash surface was most likely responsible for high specific surface of the pond ashes.

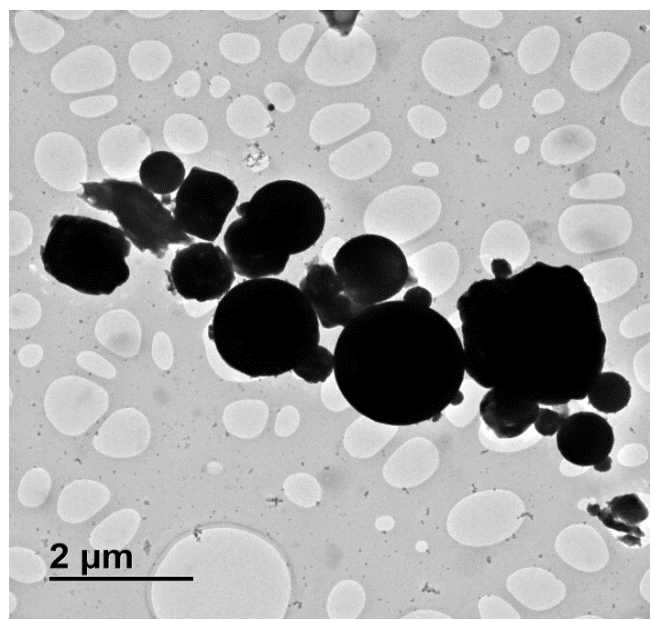

TPS4, Shivee-Ovoo fly ash

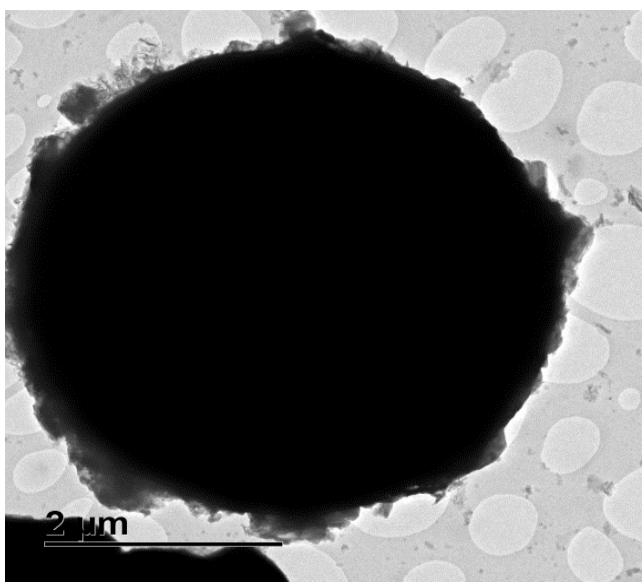

TPS4, pond ash

or leached out surfaces. It is very likely that the partially dissolved surfaces of the pond ashes were responsible for the hydroxylation. Hence pond ashes showed larger weight losses and specific surface areas than fly ashes.
TEM micrographs indicated that the surface of the pond ash was more altered than the fly ash surface. The partially dissolved and hydroxylated surface of the pond ash could be a reason of their high loss on ignition and 
high BET specific surface areas. In order to utilize pond ash in a proper way such as in alkali activated geopolymer type products' preparation, it may be necessary to destroy the highly porous microstructure of the pond ashes.

\section{ACKNOWLEDGMENT}

The present research was carried out under joint project between Laboratory of Material Science and Technology, Institute of Chemistry and Chemical Technology, Mongolian Academy of Sciences and the
CSIR Building and Construction Materials and Methods Research Group, Building Science and Technology, Built Environment Unit, Pretoria, South Africa.

\section{REFERENCES}

1. J.Temuujin, A.Minjigmaa,B.Davaabal, J.Amgalan "Characterization of granulometric composition of a Mongolian fly ash and its application for value added products" Proceedings of the $8^{\text {th }}$ International Forum on Strategic Technology 2013, p.203-206, June 28-July 1

2. J.Temuujin, A.Minjigmaa, U.Bayarzul, A.Ariunbold "Preparation of Geopolymer type binder from Mongolian fly ash and its characterization" Proceedings of the $8^{\text {th }}$ International Forum on Strategic Technology 2013, p.199-202, June 28-July 1

3. A.Palmo, M.W.Grutzeck, M.T.Blanco "Alkali-activated fly ashes A cement for the future", Cem.Conc.Res.29.1323-1329,1999

4. Jha, $\mathrm{V}$, Matsuda, M,Miyake, $\mathrm{M}$, "Resources recovery from coal fly ash waste: an overview study", Journal of the ceramic society of Japan, 116, 167-175, 2008

5. V.K.Jha, M.Matsuda, M.Miyake "Resource recovery from coal fly ash waste: an overview study", J.Ceram.Soc.Jpn.116, 167-175, 2008

6. A.Minjigmaa, Ts.Zolzaya, E.Bayanjargal, B.Davaabal, J.Temuujin, "Characterization of ash pond ashes from $3^{\text {rd }}$ thermal power plant by SEM/EDX and XRD methods", Mongolian Journal of Chemistry, 14(40), 61-65, 2014

7. MNS 5072:2001, Mongolian standard on Determination of radioactive elements content in building materials, soil and earth crust by Gamma spectrometer's method

8. J.Temuujin, "Characterization and Utilization of coal combustion by-products in Mongolia", 2014 Nova Science Publishers, Inc, Prabir Kumar Sarker, Fly Ash, Chapter 6, 165-180, 2014 